\title{
SEEDLING NATION'S CHARACTER THROUGH LEARNING HISTORY: LEARNING FROM EXILE CAMP OF BOVEN DIGOEL, PAPUA
}

\begin{abstract}
Abd. Rahman Hamid ${ }^{1}$
ABSTRACT

This article explains about the history of Boven Digoel Camp in its correlation with the formation of nation's character. From 1927 to 1930s, colonial government had been exiling politic internees there. The aims is to control their thought and attitudes towards the government. During the exile, there were two diverse characters found, as the result, there were two groups of internees found, there who change their attitudes toward the governement and those who were consistent with their political attitudes.The change was very pragmatic; it was done in order to survive in the camps and with expectation to return to their hometowns safety. However, camp life had formed solidarity and diversity spirit among the internees who came from diverse region, ethnic, language and religion. Personal, ethnical, and political view point were gradually squeezed at one place. The ideal to be a nation was increasingly strengthened particularly when they were confronted to the discriminative policies of colonial administration. These various experiences were worthy lessons for us to reflect the transformation process of our nation, Indonesia which had scarcely and expensively paid by the internees which can serve as a source of curriculum content of historical education.
\end{abstract}

Key words: history, learning, character and Boven Digoel

\footnotetext{
${ }^{\mathbf{1}}$ Abd. Rahman Hamid, lecturer of in History Department in University of Hasanuddin (Unhas). For academic interest, the author can be contacted through the office Address: Perintis kemerdekaan Street, KM 10, Tamalanrea, Makasar, 90245, and email address: abdul_pasca@yahoo.com.
} 


\section{Introduction}

“... history possesses a potency to make us humanities human, something which cannot be done by all other subjects in school curriculum (Wineburg 2006:6).

The quotation above contains an absolutely deep meaning which shows how important learning history in forming human character to be truly human beings. This meaning rhythmically similar with the vision of education, designed by Ki Hajar Dewantara, it was a perfection of human life, so we could fulfil every single need of body and soul. The Father of Education also stated that education was the existence of one's affection toward others in order to encourage a progress onto them in any field (Dewantara, 2009: 18,27). It can be found blueprints between history and education which can be established in arranging the curriculums, particularly those correlated with character building. Education is a process of making the students aware of something better, and history provides 'a million' important meaning of life in the past for the ones who want to learn it.

History learning is not merely done to transfer knowledge about events in the past, feel which sometimes make the students bored and then raise question to the benefit of what they have obtained from every single story, but it is more about efforts to form their character so that they increasingly identify themselves and their neighborhood. Without the identification, someone can lose his life orientation, along with his way of thinking and behaving in his daily life. Learning from the former people is the easiest, cheapest and wisest way to step forward better in the future life. It is only history, said Wineburg, which opens the access as wide as possible.
Boven Digoel paid an important role in the current of the history of Indonesian struggle which could not easily be forgotten, in addition to the spread of issues directed to nation's integrity which was not based on history. Until recently, we have been using the reference of national region in the area of Dutch East Indies. At least, in the 2oth century history, Boven Digul was a seedling place of struggles and independence ideals for nationalists when they were being exiled by the colonial government there and it was also a place (camp) for the heroes of independence who were arrested by the Dutch after the Round Table Conference (KMB) in 1949. The aspiration to realize an independent and sovereign nation, had forced them to be cooped up in exiling Boven Digul Camp. Because of such focus concern, the elaboration in this paper will be directed to the episode of the history of national movement which will furthermore be made as raw materials for history based character building of a generation.

\section{Boven Digoel in the Flow of Indonesian History}

The desire to realize a sovereign and independentfrom colonialism-shacklenation has madeour nation foundertotheinterment. In 1930s, colonial government was no more tolerant toward all efforts done by the heroes of national movement. It was conveyed by De Jonge when he began to administer his function as a general governor. This political attitude was caused by the background of Dutch East Indies' economy condition which was collapsed due to world's economy depression in 1930. According to him, "the matter now is not about what is wanted but what is possible". Colonial functionaries were worried of the nationalists' propaganda. For them, there were no places for agitation 
of political ideals which was not realistic, and there were places only for healthy economy management (Ingleson 1988:197).

It seemed that the unhealthy economy condition affected the political situation of Dutch East Indies. The composure and the orderliness of citizens could be disrupted by the propaganda from the nationalists. However, for the nationalists, this was a precise moment that can be advantaged to attract sympathy from the citizens so that they realized and supported their efforts to set them free from colonization. Because of this, the government tightened their subjugation towards all the activities of national heroes.

In this situation, Mohammad Hatta who just returned from Netherland on the 24th August 1932started pioneering a newstruggle organization without party identity, named by The National Education of New Indonesia (PNI Baru). In his mind, independence could only be gained through educated people's efforts. That was the reason why Hatta was very persistent to contaminate national awareness viruses to the member of the New PNI.

The other nationalist figure, who had given a big influence, was Soekarno, and just free from Sukamiskin Prison. He also did the struggle propaganda through Partindo Organization. Whereas, New PNI utilized education path, Partindo used political path in the independence struggles. Soekarno supported by the increasing number of Partindo members or masses. Through this organization, he tried to socialize his ideals about marhaenism (the have-nots) and socio-democracy. His concept was accepted in Partindo Congress in July 1933. According to Soekarno, poor people in Indonesia had to take part in the struggle of gaining Independence. Marhaenism was a principle which demanded a structure and social orderliness which served supported and facilitated the have-nots in every fields. For him, Marhaenism was a way of struggling and also a principle aimed to expel every single capitalism and imperialism (Soekarno 1964:253). Even though, aspects of political leader were preceded, Soekarno also realized the importance of education to the citizens if the independence wanted to be truly achieved (Ingleson 1988:213-214).

Both of the prominent figures had different views in the struggle of realizing the independence. Soekarno convinced more about agitation ways and propagandas in big conferences. For him, struggle spirit had to be seeded in every citizen's heart. Hatta evaluated that those ways were not exactly efficient in the middle of the repressive policies of colonial government. To guarantee the continuity of its struggle, the organization had todevotemost ofits effort totheeducation of small, discipline, and faithful cadres. For Hatta, the most important pragmatism was when the organization survived without being disrupted by government policies. Through this way, this organization in the future will therefore establish fully and bring Indonesia into independence (Ingleson 1988:218).

Every effort done by the nationalists was a threat to the colonial government which had to be handled, so that it was expected not to continue anymore, and something more important was that it would not stop colonialism circulation. Due to this, no any compromise to the nationalists couldn't be avoided. In one analysis, De Jonge said that he was actually doubt to take a decision, to stop the nationalist's figures (Hatta, Sjahrir, Maskun, Burhanuddin, Suka, Bondan, and Marwoto), because the situation was generally calm. However, he also realized that 
the leaders couldn't be left to continue their struggle because it could affect the situation in the country. For him, the composure and the orderliness are above all (Ingleson 1988:251).

Earlier in February 1934, Soekarno along with his wife and some of his partners were exiled to Endeh, Flores. In the same year, Hatta, Sjahrir, and others are brought to Boven Digoel. According to John D. Legge, Soekarno's exile place was far location than of Hatta and Sjahrir's interment which was usually called "The Hell of Red Land". However, both of these places had 'broken nationalists' wings', Mohammad Hatta wrote in his letter to Murad in the 2oth of April 1934, published in Daulat Ra'jat newspaper, on the 10th of May 1934 (Rose 1991:127,151). The broken wings didn't mean the end of their struggle for independence, but it became a new arena which had to be utilized properly to whip up the spirit of service to the nation's struggle. Soekarno used his pens, wrote neutral political writing in press on media to spread struggling spirit to the whole nationalists (Legge 2001:167-169).

Red Land was a jungle area which was full of threats like wild animals, diseases (malaria) and even cannibalism done by local villagers. This region was opened for camp on January 1927.

In a secret letter from the General Governor, De Graff to the Governor of Maluku, it was written that The Red Land had to be as a place where political ambitions should be replaced by more mild and more social in term of interests. It seemed that the government applied the policy of "Normality Ethic". Henceforth, Pontjopangrawit was given a chance to make Gamelan Digul in Tanah Tinggi in 1927 (Kartomi 2005:58). Accroding to Salim's point of view (1977:297), this policy was only a political reason from the authorily of the Javanese people to their hometown. Furthermore, the government influenced them to work (as werkwilliger) by tantalizing them a hope to go back to their hometown someday.

In Mas Marco Kartodikromo's diary (2002), published in Pewarta Deli newspaper from October 10th until December 9th 1931, as a person who had ever been exiled in Boven Digoel, it was known that the region was previously used as a interment location for communists who performed rebellion in Java in 19. In that place there were 14 barracks. Each was 14 meters length and 4 meters width with sago palm-roofed and rubber sheet-walled. One of barracks was used as a hospital and others as living place for the internees. Their faces were unhappy. Most of their bodies were full of wounds of the bite of leechand other small animals which lived around the jungle. Every internee got a room of $2 \times 2$ meter to sleep and $2 \times 2$ meter to eat and to save their stuff. At the time, Mas Marco arrived there in June 1927, the roads and the village of the internees were still in bad condition. Besides, the barracks, had 12 houses with $4 \times 4$ meter size who were built by the internists originally from Betawi, Bandung, Cirebon, Semarang, Surabaya, and others.

Every internee borrowed from the government, a small sleeping net, mat, blanket, blunt machete, legless axe, and handless hoe. At 5 a.m, they were awakened by the soldiers who escorted them to the jungle, so that they were far away from roads or access and also from a settlement. They worked under military control just like unskilled laborers in Java. They were gathered when it was the time for them to get their wage. If one's name was called but 
he was late, the Lieutenant wouldn't give his wage and even he was asked to go home.

If we observed carefully their way of life, according to Salim (1977:269-279), they were divided into four groups. First, a group who were willing to work. Most of the internees chose this way of life. They worked in governmental bureau, hospital personnel, malaria extermination service and warehousing laborers or outdoor laborers. Second, a group who did self development projects like fisherman, vegetable farmers, store and stall entrepreneurs. As long as they couldn't able to support their life necessity, they were given subsidy by the government in form of fifteen-kilogram rice each month. Third, a group who received subsidy, they were people who suffered from severe diseases which had a small chance to recover. Among them were malaria sufferers who had been suffered from this disease for years, kidney, TBC, and nerves diseases. However there were some people who were both actually physically and mentally healthy but pretended to suffer some diseases so that they could live happily and had subsidy without working. If they were caught red handed, they were forced by the doctors to drink castor oil mixed with quinine poured into their mouth while a nurse pinched their noses. As a result, the deceivers would usually say that they had recovered in one day.

The last (the fourth), naturalist or principal groups, people who declined every job assigned by the government and only received a subsidy in form of natural food from the government. This group based their attitudetothegovernmentswhilebeingexiling that they were not prisoners so they were not obliged to work. Although the government didn't deny their conviction, they were regarded to rebel against the government.
Naturalists behaved indifferently toward all the colonists together with their followers except the doctors. They always conducted demonstrations and rebelled injustice every time colonial officials came to visit their place. Even though their conviction was right, they were not determined to be returned to their hometown.

In the early of the restraint, the naturalists were exiled into the second internment level. They were arrested in a sudden and carried away by a motor boat so as to remove to Tanah Tinggi camp. Their life and condition in the last camp were far more difficult Tanah Merah camp (Salim called it the first level camp). From all internees' groups, the naturalists were viewed as the riskiest.

On the 28th of January 1935 Hatta, Sjahrir, Bondan, and others arrived in Tanah Merah. They found two villages of the remained exiled people, previously seven villages named nomenclature village or Kampong A until G. Five other villages, except for A and B, had become shrub places again, along with the beginning of repatriation of internees class by the government in 1931. "When we arrived, the exiled people lived in Digul were about 900 people remained, besides their wives and children", Mohammad Bondan wrote in his memoir (2011:44).

In the second day, the Chief of Local Government Captain Van Langen, gave them chances to choose their status, whether as the naturalist or the werkwilliger. People who were not eager to work to the government were called the naturalist. Every month they received food in a natura way from the government. The rations accepted every month consisted of: $18 \mathrm{~kg}$ rice, $2 \mathrm{~kg}$ salty fish, 300 grams tea, 300 gram green bean and 2/3 lemonade bottle of coconut oil. People 
eager to work to the government were called. They received wage 40 cents per day. Their tasks were to plough ditches, to dig gutters and sorts of that. They started working from 8 A.M until 12 A.M. The werkwilliger class would someday be able to be sent back to their original hometowns because they were regarded loyal to the government.

The election of status was affected by their neighborhood (village) where they lived. The naturalist class occupied Village A and the werkwilliger class occupied Village B. The distance of both villages was connected by a two-meter width street. Every village owned one field which was used to play soccer in leisure time (Hatta 2011:148).

The entire internees arriving together with Hatta chose naturalist status, except for Murwoto. Even though their choice was different, they didn't compete against him because theywere comrades in the revolution. In their daily social intercourse, there was no distance between naturalist and werkwilliger class. They tried to diminish social gap and conflict among them due to the status. It seemed that they didn'twant to repeat conflict story among internees class which had ever happened before. Diverse point of view from their origin was still carried into the exiling land that it often triggered conflicts among them (Kartodikromo 2002).

In addition to both above categories, there was one more category called onverzoenlijken (those who constantly rebelled). From the beginning of the exile period, this class constantly rebelled and refused to obey government's rules, even if it was their own importance like cleaning their own yard. They were sent to Tanah Tinggi. It took one day from there. They did not want to make their own house and village. As a result, they lived in an available barrack. There were about teens of them. During their living in the camp, they were strictly monitored by military company. If someone was sick, they would be taken to Tanah Merah to have some treatment. If he had recovered, he would be taken back to the barrack. Hatta's note (201:149) said that among them there were someone who were did not survive prolonged in Tanah Tinggi. Such people usually gave up and chose to work to the government; and then his status would be renewed from onverzoenlijken into werkwilliger.

The internees' live were abundantly diverse. They spent their days by doing various activities which could make them revive to face natural neighborhood of Papua which was green but scaring. Tanah Merah camp environment was surrounded by Digul River where many crocodiles lived there. There were also many wild animals roamed that great jungle. It was more horrible by cannibalism conducted by which was still prevailed for the native Papua. Those conditions madetheinternees didn'thaveany other choice for surviving in the exile camp. Furthermore, they also had to be strong enough to endure colonial government who did not treat them as the internees (exiled people), not prisoners, as they used to be promised to act freely in Boven Digoel (Salim 1977:296). In the reality, the government paid much interference in their life. To face such condition, the internees chose their own way of life as the naturalist class, the werkwilliger and the onverzoenlijken.

In the internees, the activities of art, sport and learning were improved. They formed an opera group named Orient and Liberty and an association of Sundanese theatrical troupe named "Penglipur Hate" or "The Relief". From many entertainment 
groups available, Ketoprak Association and Human Puppet Association could survive in a long period. The sole group which could endure during internee period was Kunst en Sportvereniging Boven Digul, with its band named Digul Konsert. With this entertainment the circumstance of this camp seemed to be alive, even though the desire to return back to their hometown was the most expected one. The other play which was also entertaining and attractive was gamelan.

Sport activities was generally in a form of PencakSilat.Therewere someSilatstyles popular among exile camp community, such as "Setia Hati" or (Loyal Heart) style and Minangkabau style. There was also Jakarta silat style, its master was Sumatera people. Every time a celebration existed in the camp, silat show was performed into the camp which attracted Dutch guests. Besides silat, there was also a group playing judo or jiujitsu and boxing.

Javanese people were infatuated with art activities while Sumatera People preferred to pencak silat. The diversity of the interest had ever advantaged by the colonial government to play ones against other, but it didn't work yet especially in 1930. Their solidarity strengthenedmorewhiletheywereconfronted to a situation against colonial administration side. "It was thoroughly inculcated nature", Salim recalled (1977:364).

The activities of painter and drawing specialists' group focused in the river bank and in the jungle. Their paintings were offered to internees' villages. The soldiers and the visitors were their customers who dared to expensively pay for their painting. Learning activities were also got along. If compared to the previous activities, these learning activities would very limited. Even if there was a school built by the government, it was only specialized for the werkwilliger class, and the teachers were assigned from internees group. Naturalist formed study clubs where the members were not more than three persons. If the members were more than three persons, it was against the colonial government's rule. The activities were carried out in the naturalists' houses. The learning system was called "Sistem Tiga Keluarga" or "Three Families System". In the system every class consisted of three students only plus one teacher. The teacher was not paid, even he was willing to sacrifice his own belonging, if it was necessary. Then, if the teacher was arrested by the government, the oldest would be responsible to replace him. This school was called Malay English School (MES). Its material was primary school standard, plus English lesson (Bondan 2011:49).

After three months in Tanah Merah, Hatta began to perform a course. There were three materials which were given, they were philosophy, economy and history. These learning materials were then published in a brochure named Alam Pikiran Yunani or Greek Philosophy. After being published into a book, with the title above, Hatta made it as his bride price to his wife. This activity was done until Hatta (and Sjahrir) were removed to Banda Neira in November 1935.

Every month, Hatta and Sjahrir got a package from Netherland whisch contained three kinds of newpapers, Het Volksblad, De Groene Amsterdammer, and Nieuwe Rotterdamsche Courant. Bondan received Soeara Umum and Mingguan Umum newspaper, and also Pemandangan newspaper from Surabaya. All the papers were consumed by naturalist class, or at least conveyed by the teachers of MES to their students. Shortly, the naturalists class did not miss reading sources that they constantly enriched their ideal horizon while their living in Tanah Merah. 
Besides the newspapers packages, Hatta himself brought his books amounted 16 cases when he was exiled to Tanah Merah. He spent his days reading and writing. Every morning from 8.00 until 11.00 or 11.30 or after walking around kampong $\mathrm{A}$ and kampong B, Hatta read philosophy books such as written by Wilhelm Windelband, Praludien first and second edition and also his book Lehrbuch der Geschichte der Philosophie. Then he cooked rice and boiled vegetables. Twice a week, Hatta gave a course to Boerhanuddin, Bondan, and Suka, about economy and philosophy. This activity was started between 10.00 p.m and 11.00 p.m after dinner. During in this exiling period, Hatta had suffered from severe malaria twice. He had to check up regularly to the hospital and took medicine according to the doctors' prescription and suggestion in Wilhelmina Hospital. This hospital was near Digul River but now it has been collapsed and only the oundation remains.

At the end of February and early March 1935, Hatta wrote a letter to his brotherin-law, Dahlan Sutan Lembaq Tuah. In his letter he told about the condition there, for example about the division of internee's class between naturalists and werkwilliger, and also the acceptance of every-month rations which cost equaled a half price of food for the prisoners (in prisons). Hatta also told about his desire to build a house by himself which could endured for 10 years. To this last intention, Hatta demanded that he be sent tools of trade to build the house.

However, Dahlan exposed his letter to the chief redactor of Pemandangan newspaper, Saerun's relative. The letter was then quoted by some other newspapers, including the Dutch newspaper. The content of the letter eventually read by the chief of Anti Revolutionary Party, Dr. H. Collijn.
He reacted violently toward The Dutch East Indies Government. In his speech in Tweede Kamer, Collijn conveyed that "to interne Mohammad Hatta in Boven Digul was to separate him from his people and not to annihilate him" (Hatta 2011:154).

After the news of Hatta's condition had spread over, he was then removed to Banda Neira in November 1935, together with Sjahrir. The condition of this internment was much better than that of Tanah Merah. In this place, Hatta met some of national movement heroes who were previously exiled by the colonial government; they were Mr. Iwa Koesoema Soemantri and Dr. Tjiptpo Mengoenkoesoemo. Due to the same revolutionary vision preceding education and teaching, Hatta also performed learning activities in Banda Naira, just like what he had ever done in Tanah Merah. His students were the internee class and also the indigenous' children who then became his adopted children.

The improvement and the exchange of world politic in 1941indicated that The Dutch East Indies would be interested in Pacific War. This of course would affect the continuity of colonial administration in the Dutch East Indies. In the middle of this condition, at the end of January 1942, Hatta got a telegram from the government so that he and his wife, and also Sjahrir prepared themselves to be removed to Sukabumi. They were taken away by Catalina plane on the 1st February 1942. Not too long after their arrival in Java, the troop of Japan landed in Banten. On the 9th March 1942, Japan was successful to take over the administration from the Dutch. It was the time when the national movement's figures were freed from the Dutch colonization grip. However they had to struggle and fight this new colony for more than three years before finally 
Indonesia obtained its independence on the 17th August 1945 .

In the circumstance of Pacific War, the fate of the internees in Boven Digul was unstable. Their condition was very saddening. Their food necessity in the camps was insufficient and limited. The internees had to find their own logistic sources in the jungle and around the rivers. Some of them who still endured to live in Boven Digoel were influenced by the Dutch to fight against Japan fascism. But there were also some people who advantaged this moment to leave the internment. Bondan, along with the other internees, left Tanah Merah, helped by the natives of Papua, to Merauke. On behalf of Dutch Governemnt, Van der Plas passed the policy of internees' evacuation to Australia, started from May, 29 until June 10, 1943. They were evacuated by vessels and planes. As a result, there were 600 people in Horn Island, Australia. The ship in which Bondan went with arrived in Brisbane Harbor on the 23 rd of June 1943. There were about 20 trucks utilized to evacuate Digulis people together with their family (Bondan 2011:5473). In this new place, they kept fire of the revolution. And finally on the 18th of August 1945, they accepted the news that Soekarno and Hatta had proclaimed the Independence of Indonesia a day before.

\section{The Nation's History and Character}

The explanation above shows that the process to be a sovereign nation is very expensive paid by our nation's founders. They were forcefully, without real court process, kept away from their family and their hometown. But their desire always kept growing stronger to fight the revolution, regardless to though their movement space which was very limited. Boven Digoel camps became a place to spend their time. In this moment, they had opportunities to meet and communicate with the other figures from various regions, ethnics, and religions. In this process, the camp was just like a "miniature of Indonesia" in the internment land (Kartomi 2005:61).

Previously, the colonial government tried to make advantage of this diverse condition to create a conflict, especially between Java and Sumatera (Minangkabau). Art activities were infatuated by Javanese while Sumatran preferred to spend their time most in sport activities like pencak silat. Both of this activities were so conspicuous enough that the participants wanted to be provoked by the colonial government. Unfortunately, this effort didn't work out because the internees, especially those who came in 1930s, had high solidarity values as the exiled revolution mates. Their solidarity was strengthened particularly when they were exposed to the colonial government. Shortly, the solidarity among the internees was fundamentally built as a similar revolution purpose; to chase away the colonist and gained the independence. Related to this aspect, it can be concluded that the diversity possesses a big potency to be advantaged as the nation's unity and adhere; vice versa, if it is not properly managed, it will be a source of conflict. The treatise of the internees' lives have reflected the implementation of Bhineka Tunggal Ika principle.

The history of the internment or the exile in Boven Digul camp gives us a great worthy lesson about the naturalists' consistency. They were viewed as the most consistent among all the other groups in the exiling place. They kept preceding their noncooperative attitude so that every single effort of government to persuade them to work, 
even with wage, was rejected by them. They kept the colonial promise that their status in the internment was as the internees, not prisoners, so they didn't have an obligation to work. The figure of true naturalists can be made as a referee was Mohammad Hatta. In his conversation with Captain van Langen in Tanah Merah, Hatta was offered a very high salary, with one condition that he was eager to cooperate with the colonial government. Hatta rejected the persuasion to cooperate. This was the second time he refused to cooperate, because at the time he was in Jakarta, he was also offered the same offer from the colonial government. "I am still a non-cooperator", said Hatta (2011:150).

Another lesson which can be learned from this history is self-awareness of the importance of education among theinternees. Even if the government had prevailed a policy to prohibit learning activities (schools), they kept finding these alternatives. They formed a small learning club called "Sistem Tiga Keluarga" or "Three - Family System". This system was very effective. The interaction between the teachers and the students was more intensive.

They also didn't need a special learning class like schools in general. Learning activities could be done anywhere and anytime, as long as the teachers and the students were available. It was true that many teachers were needed to perform this learning system. One thing that should be deserved to be appreciated was the willingness of the teachers eventhough without being paid. Even the teachers were willing to give their belonging just to make the learning activities worked. The viruses of learning lovers were infected by Hatta, who was from the beginning well known in discipline in learning, to all of them. He had various books collection which he brought to
Tanah Merah. If he needed, he would lend his books to the internees based on the time scheduled. His love and interest in books were revealed in his life philosophy, "As long as I have books, I can live anywhere". He also reminded us to "struggle as long as we are free, if our wings have been broken, let's dedicate ourselves to find out knowledge" (Rose 1991:127).

Various experiences and lessons from the history of the exiled national movement figures in Boven Digoel are very important to be comprehended by the educators and the students. There are two ways which can be done to transfer the historical knowledge.

First, the improvement of historical tourism activities. The students are invited by the teachers to visit and recognize closely the historical objects. Through this way they can inspire every single pulse of the internees' life at their period. The observation toward the disposition and condition of Boven Digoel camp, whether in Tanah Merah or in Tanah Tinggi, will bear their inspiration and evaluation toward the objects and the condition of the settlers while the camp was settled. To give them knowledge and inspiration, the teachers need to own good firmament and horizon toward the intended objects, or at least, they can use a guide if available in the location.

Second, the production of recording raised from the output of outdoor visitation and reading materials from historical sources. The students are not only involved directly to the visitation activities but also invited to reconstruct past events from the the object in the form of audiovisual. Henceforth, they will not only consume the information but also produce knowledge about the historical object which they visit. In this context, the studentshad recreated thepasteventmemory 
(story) to the importance of learning and the formation of their character as the nation's generation.

Through both ways mentioned above, it is expected their awareness will grow stronger to accept their Indonesian reality which has expensively paid by the internees. They can also compare the condition of that era and the condition they have now, so that they can be thankful generations and eager to learn from their ancestors' experience. While in the exiling period the internees were still able to learn more and to think about the importance of their nation (future), so how about the recent generation's thought and attitude? This case can be answered if they have good historical knowledge and awareness.

\section{Conclusion}

The opening of Boven Digoel camp was opend by the Dutch colonial government was intended to form and also to change the characters of the settlers. For the government side, internment tended to be an effort to normalize their ethical life so that they were more ccoperative with the government. In contrast, for the national movement figures who experienced and spent their life there, the camps was just like world hell which they experienced due to their struggle to fight the independence. Whatever their point of view toward the interment place, there was something surely happened; the camps had formed the Indonesian character which was strong and weak. The weak belonged to those who change their conviction while they were in the internment. On the other hand, the strong were those who stood still in their conviction whatever happened, or they were often called as the principle.
The exiled people in Boven Digoel were generally divided into two. First, the communists who conducted rebellion in 1926. Due to this rebellion, they were exiled to their hometown. Second, the nationalists or national movement figures who were exiled in 1930s. Their placement in the internment was suited to their status chosen while the first time they arrived in the camps. The alternation of status often occurred, from the non-cooperative to cooperative, especially after they had experienced different camp condition. The condition of the internees in Tanah Merah was far better than that of internees who settled in camp Tanah Tinggi.

The refreshment of nation's past event knowledge is a valuable treasure which can be advantaged as foundation of generation's character formation as well as learning materials character-based education. The opening and the functioning of Boven Digoel camp left various valuable learning which has to be known by the generation of our nation. (Indonesian) as a nation where we settle now is not formed by itself. The revolutionists had expensively paid their dreams to be an independent and sovereign nation which we enjoy now. The history of our nation provides various lessons which can serve as a model of the formation of the nation's characters.[]

\section{REFERENCES}

Bondan, M. (2011). Memoar Seorang EksDigulis: Totalitas Sebuah Perjuangan. Jakarta: Kompas.

Dewantara, K.H. (2009). Menuju Manusia Merdeka. Yogyakarta: Lautika.

Hatta, M. (2011). Untuk Negeriku: Sebuah Otobiografi 2nd Edition (Berjuang dan Dibuang. Jakarta: Kompas. 
Ingleson, J. (1988). Jalan ke Pengasingan: Rose, M. (1991). Indonesia Merdeka: Pergerakan Nasionalis Indonesia Tahun 1927-1934. Translated by Zamaksyari Dhofier. Jakarta: LP3ES.

Kartodikromo, M. M. (2002). Pergaulan Orang Buangan di Boven Digoel. Jakarta: Kepustakaan Populer Gramedia. Biografi Politik Mohammad Hatta. Translated by Hermawan Sulityo. Jakarta: Gramedia Pustaka Utama.

Salim, I. C. (1977). Lima Belas Tahun Digul: Kamp Konsentrasi di Niew Guinea. Translated by Hazil Tanzil dan J. Taufik Salim. Jakarta: Bulan Bintang.

Kartomi, M. J. (2005). Gamelan Digul Di Balik Sosok Seorang Pejuang: Hubungan Antara Indonesia dengan Australia. Translated by Hersri Setiawan. Jakarta: Yayasan Obor Indonesia.

Soekarno. (1964). Dibawah Bendera Revolusi. Jakarta: Panitya Penerbit Dibawah Bendera Revolusi.

Legge, J.D. (2001). Sukarno: Biografi Politik. Translated. Jakarta: Sinar Harapan.

Wineburg, S. (2006). Berpikir Historis: Memetakan Masa Depan, Mengajarkan Masa Lalu. Diterjemahkan oleh Masri Maris. Jakarta: Obor Foundation of Indonesia. 